\title{
3D Modelling, Design and Safety Management in High Rise Building using Bim
}

\author{
Mohammed Waheed, Mahmad Naheed, Parvez Patel, Syed Mubashir Hussain, A.B Harwalkar
}

\begin{abstract}
In this works 3D modeling, design and safety management of high rise building using building information modeling (BIM) technology is carried out.. Initially a AutoCAD plan with all its salient features is developed following byelaws of high rise building. Then the $3 D$ modeling and rendering of high rise building is done in the Revit architecture of the $2 \mathrm{D}$ plan which is imported from the AutoCAD. The analysis and design of high rise building is carried out using ETabs software. Apart from the structural design Mechanical, Electrical and Plumbing (MEP) services design is carried out using BIM technology. The layout of fire safety system is specified efficiently with use of BIM in co-ordination with MEP services. The application of BIM based design process resulted in considerable time reduction in compression with traditional design process and the holistic design of the high rise building is carried out with the compatibility of different softwares.
\end{abstract}

Keywords : High Rise Building; Bim; Mep; Fire Safety.

\section{INTRODUCTION}

$\mathbf{P}_{\text {lan and 3d model with great elevation, detailed }}$ diagrams, and V-ray rendering are all provided by the Revit Architecture software. Building information modeling (BIM) provides information on project design, its various views, scope, numbers, and phases when you need it. Every project In Revit the model will include 2D, 3D, and section views. elevations with detailing and schedules. Revit Architecture gathers data on each structural element's material, its realistic visualization, and its design, such as thickness and height, and in the schedule, it will provide a number of data points such as cost, family type, number of bricks, number of doors, number of windows, and so on, across all other representations of the project. We can have all of these 2D, 3D, and sectional views, as well as elevation and

Manuscript received on September 08, 2021.

Revised Manuscript received on September 15, 2021.

Manuscript published on October 30, 2021.

*Correspondence Author

Mohammed Waheed*, B.E student, Department of Civil Engineering PDA College of Engineering kalaburagi-585102, Karnataka, India. Email: Mdwaheed031@gmail.com

Mahmad Naheed, B.E student, Department of Civil Engineering PDA College of Engineering kalaburagi-585102, Karnataka, India. Email: nsk8616@gmail.com

Parvez Patel, B. E student, Department of Civil Engineering PDA College of Engineering kalaburagi-585102, Karnataka, India. Email: parvezpatel2419@gmail.com

Syed Mubashir Hussain, B. E student, Department of Civil Engineering PDA College of Engineering kalaburagi-585102, Karnataka, India. Email: syedmubashir1997@gamil.com

Dr Aravindkumar B Harwalkar, Associate Professor Department of Civil Engineering PDA College of Engineering kalaburagi-585102, Karnataka, India. Email: harwlkar_ab@yahoo.co.in

(C) The Authors. Published by Blue Eyes Intelligence Engineering and Sciences Publication (BEIESP). This is an open access article under the CC BY-NC-ND license (http://creativecommons.org/licenses/by-nc-nd/4.0/) detailed drawings, in one full sheet in Revit. The goal of structural design is to achieve a reasonable likelihood that the structure will fulfill the purpose for which it was intended and will safely resist the forces acting on it during its useful life.

Temperature swings, foundation settlements, and other factors should all be taken into account. The working stress technique, ultimate load method, and limit state approach are 位ized in the design of reinforced concrete buildings. For slabs, beams, columns, and stairwells, the selected approach is the limit state method. The limit state technique requires the structure to be built to withstand all loads likely to act on it over its life while also meeting serviceability standards such as deflection and cracking limits.

\section{BUILDING INFORMATION MODELING (BIM):}

"A digital representation of a building's physical and functional features that is shared/used by all stakeholders to imize waste and enhance efficiency," according to BIM. such, it acts as a common knowledge repository for tion about a facility, providing a solid foundation for cycle. A fundamental takeholders at various stages of a facility's life cycle to input, remove, update, or alter information in the BIM process to pport and represent each stakeholder's function. BIM Building Information Modeling, which is a shared representation based on open standards for When BIM is utilized throughout the process, however, it ensures that transportation is mooth. With a high level of detail BIM model, managers can cess vital information about every nook and cranny of facility. Building information modeling, or BIM, is an intelligent digital representation or model-based method for planning, designing, building, managing logistics, and carrying out operations and maintenance processes. It allows the builder to display the building according to its physical and functional features and provides a high level of information integration for the construction process.

\section{LITERATURE REVIEW}

> Rakesh Reddy E, and Kailash kumar S, (2019) studied on Design And Modeling Of G+5 Commercial Building By Autodesk Revit Architecture".

They concluded,

The project gives the realistic modeling of building and accurate families ranging from furniture to lighting fixtures, as well as import existing models from other software's like Auto CAD etc. 


\section{D Modelling, Design and Safety Management in High Rise Building using Bim}

> Sayyed Feroz Sikandar, et al. (2019) studied on Analysis and Design of Multistory Building Using ETABS 2017.They concluded,

Analysis and design of building having G+10 storey's by using the ETABS software.

$>$ Miss. Irin Ann Isac, Dr. Anoop C K (2019) studied on "Analysis Of Building Information Modelling And Scope Of BIM In India”. They concluded,

BIM Digitalises the life of a building or a group of buildings to deliver optimised solutions in every phase from its conception to demolition.

\section{a. Objectives}

Following are the objectives of the project work:

1. To develop a $2 \mathrm{D}$ plan of high rise building $(\mathrm{G}+13)$ using BIM concept.

2. 3D Modeling and detailing of high rise building in REVIT software.

3. High-rise building analysis and design in ETABS software.

4. Structural detailing of high rise building.

5. Mechanical Electrical and Plumbing (MEP) 3D modeling by using BIM concept from the criteria of safety management.

\section{b. Scope Of The Work}

1. Modeling of high rise building with high graphical and good aesthetical visuals of rendered models which includes exterior as well as interior families consisting of various furniture and residential appliances, sighting the compatibility of both AutoCAD and Revit software the models are imported from AutoCAD software to later work upon in Revit.

2. By using ETABS software Analysis and Design of $(\mathrm{G}+13)$ High rise building, components of a building structure like beams, columns, stair, and foundation is designed according to the standard specifications.

3. The building services MEP and for safety management fire layout id designed using BIM.

\section{METHODOLOGY}

\section{SOFTWARES USED:}
a. AUTOCAD
b. REVIT
c. ETABS

\section{A. CONCEPTUAL PLANNING:}

- $\quad$ Planning\& designing of high rise building using Auto CAD.

- Auto CAD permits to draw 2D drawings such as plans, elevations and sections, can place doors, windows, ventilators and can place structural elements like walls, beams, columns, and slab.

B. 3D MODELING:

- For each structural element, the Revit Architecture will provide a plan view, 3D model with great elevation, detailed diagrams, and schedules.

- Every project in the Revit model will offer us with 2D, $3 \mathrm{D}$, section views, elevations with details and schedules, as well as quantities..

$>$ REVIT means Revised instantly which includes

a) Revit architecture

b) Revit structure

c) Revit MEP (Mechanical Electrical Plumbing)

\section{ANALYSIS AND DESIGN:}

- Analysis of the proposed plan in ETABS with different load combination.

- Modeling of the high rise building with structural details.

- Structural design of high rise building.

\section{Building bye laws and regulation}

The building bye laws oversee the following rules and regulation of building features:

1. Setback or building line.

2. Floor area ratio (FAR) or Total built-up area.

3. Open space requirement all over the building.

4. Plan showing internal dimensions of rooms, kitchen, living etc.

5. Cross sectional details showing heights of building and floor height.

6. Lightening and ventilation of rooms.

7. Structural details and design.

Floor area ratio

As per the NBC code-2016 for clear understanding, the built up area v/s plot area is follow:

Table 1

\begin{tabular}{|r|c|c|}
\hline $\begin{array}{r}\text { Sl } \\
\text { no }\end{array}$ & Plot area & $\begin{array}{c}\text { Max allowable built-up } \\
\text { area }\end{array}$ \\
\hline 1. & $<200$ sqm & $60 \%$ with 2storied structure. \\
\hline 2. & From 200-500sqm. & $50 \%$ of the plot area. \\
\hline 3. & From 500-1000sqm. & $40 \%$ of the plot area. \\
\hline 4. & Above 1000sqm. & $33.33 \%$ of the plot area. \\
\hline
\end{tabular}

While preparing the plan the following bye laws are used:

- The maximum allowable built up area is 33\% for the area 1000sqm and above.(NBC 2016 ).

- For building height of $45-$ to- $50 \mathrm{~m}$ the setback in all direction should be $13 \mathrm{~m}$.

( as per NBC 2016 table 2 of part 3)

- The minimum no of staircase and lifts for high rise building is 2.( NBC part 4).

- The width of staircase varies from $1 \mathrm{~m}$ to $2 \mathrm{~m}$ for high rise building. (NBC part 4).

\section{PLAN OF THE BUILDING}

The plan of the residential building $(G+13)$, used for the current project work, is developed using autocad and is shown in fig 1 . The salient features of the proposed building are shown below:

TOTAL AREA

$>$ TOTAl BUILT UP AREA

$>$ AREA OF 2BHK BLOCK $=140 \mathrm{SQM}$

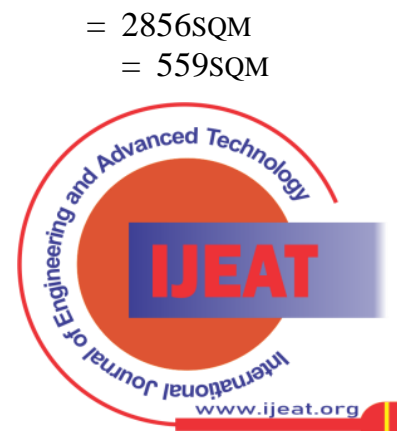




$\begin{array}{lll}\text { FLOOR HEIGHT } & =3.5 \mathrm{M} \\ >\text { NO OF BLOCKS IN EACH FLOOR } & =4 \\ >\text { TOTAL NO. OF FLOORS } & =13 \\ >\text { NO OF STAIRCASE } & =2 \\ >\text { NO OF ELEVATORS } & =2 \\ >\text { COMMON CORRIDOR } & =1\end{array}$

The schedule of openings of doors, windows and ventilators are shown in table 2 below:

SCHEDULE OF OPENINGS

Table 2

\begin{tabular}{|c|c|c|c|}
\hline 1. & Doors, & M.D & $1.2 \times 2.1 \mathrm{M}$ \\
\hline 2. & & D & $1 \mathrm{X} 2.1 \mathrm{M}$ \\
\hline 3. & & D1 & 0.75 X 2M \\
\hline 4. & Windows, & W & $1.2 \mathrm{X} 1.2 \mathrm{M}$ \\
\hline 5. & & KW & $1.2 \times 0.9 \mathrm{M}$ \\
\hline 6. & & V & $0.6 \mathrm{X} 0.6 \mathrm{M}$ \\
\hline
\end{tabular}

\section{CREATING PLANS IN AUTOCAD}

The typical floor plan, column centre line diagram and plan showing column-beam layout are shown in fig.2,3\&4 respectively:

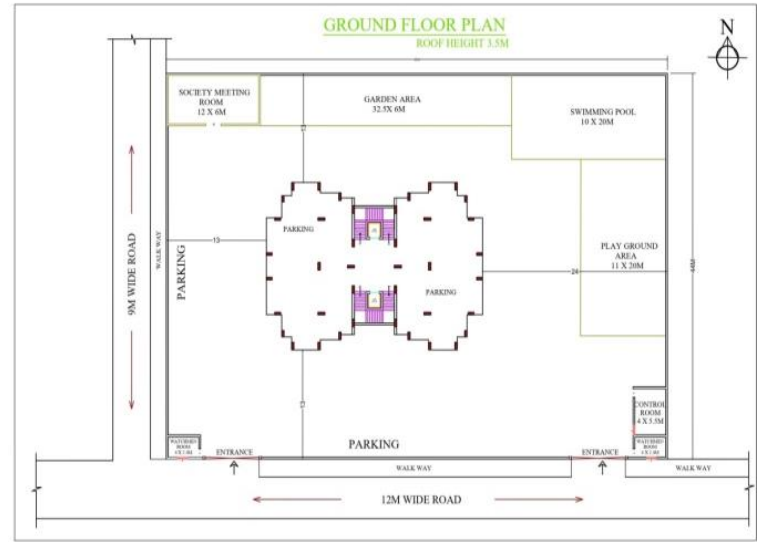

Fig1, Ground Floor Plan of Residential Building.

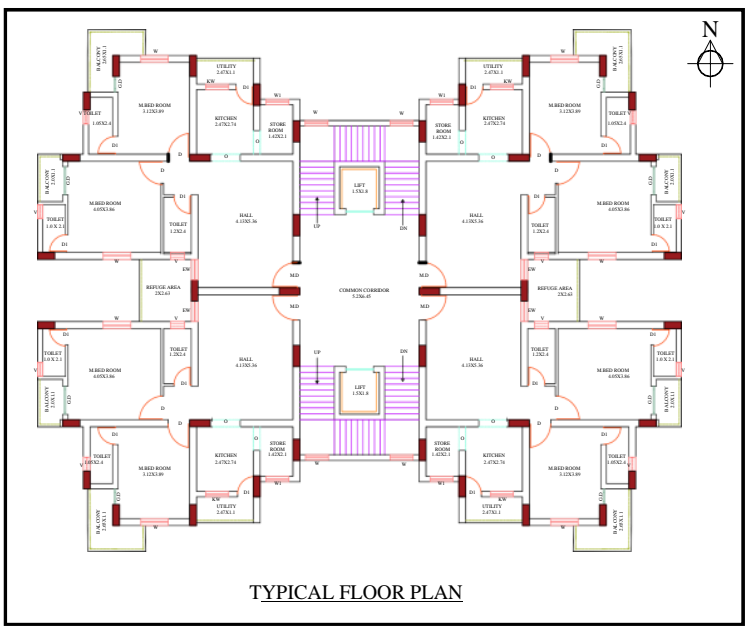

Fig2, Typical Floor Plan of Residential Building.

Retrieval Number: 100.1/ijeat.A31311011121

DOI: 10.35940/ijeat.A3131.1011121

Journal Website: www.ijeat.org

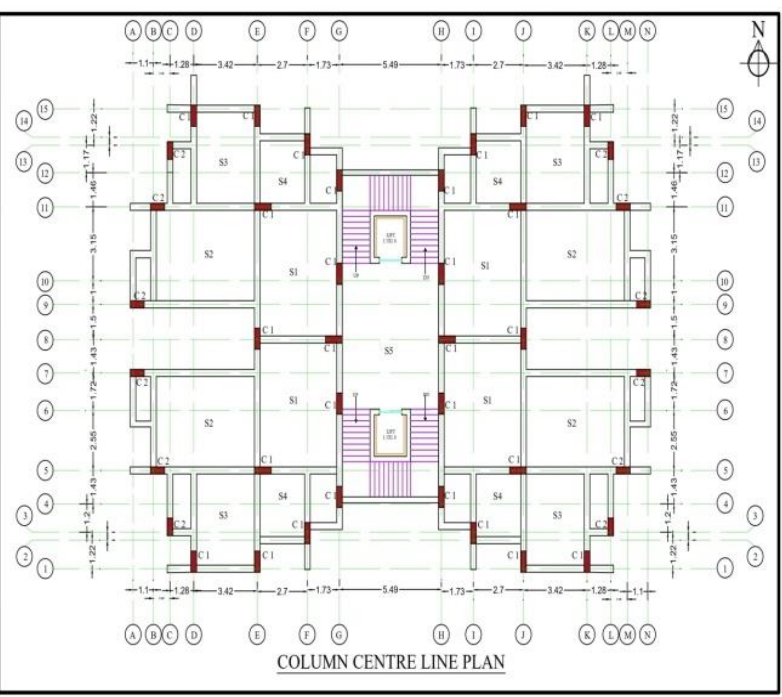

Fig3, Column Centre Line Plan.

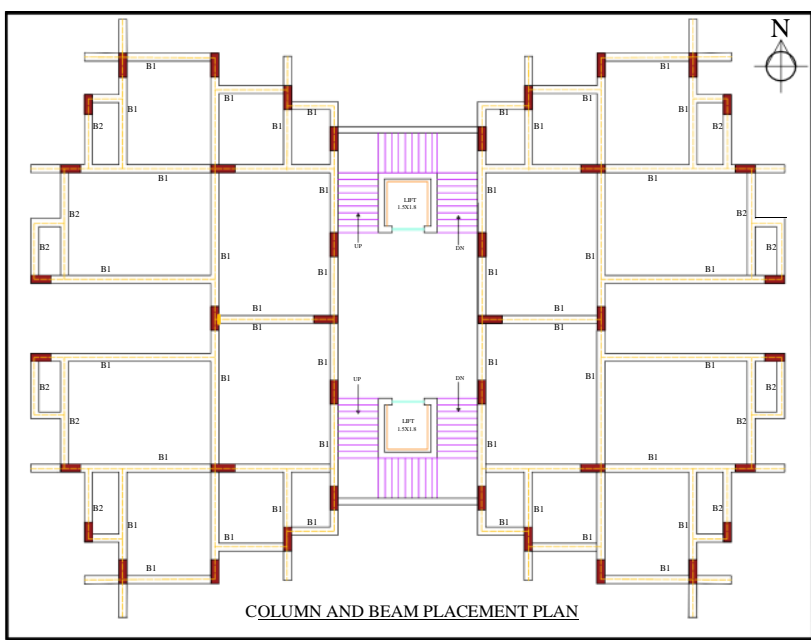

Fig4, Column Beam Placement Plan

Architectural 3D Modeling

Steps involved in completing the $3 \mathrm{~d}$ modeling of a building:

1. Creating a Project

2. Name and Save the Project File

3. Zoom To a View

4. Rename Levels

5. Components

6. Creating walls

7. Adding doors

8. Adding window

9. Adding a roof

10. Adding a Ceiling

11. Adding a Floor

12. Adding stairs and railings

13. Adding Material

14. Placing a Component

\section{CREATING 3D MODELS IN REVIT}

$3 d$ rendered floor plan of high rise building in Revit as shown in fig $5 \& 6$ below:

Published By:

Blue Eyes Intelligence Engineering and Sciences Publication (BEIESP) (C) Copyright: All rights reserved.

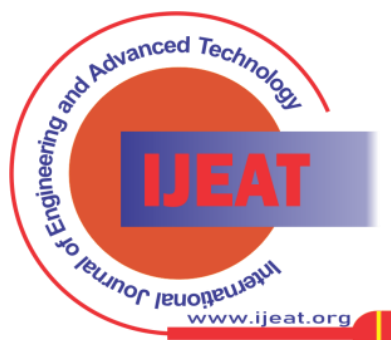




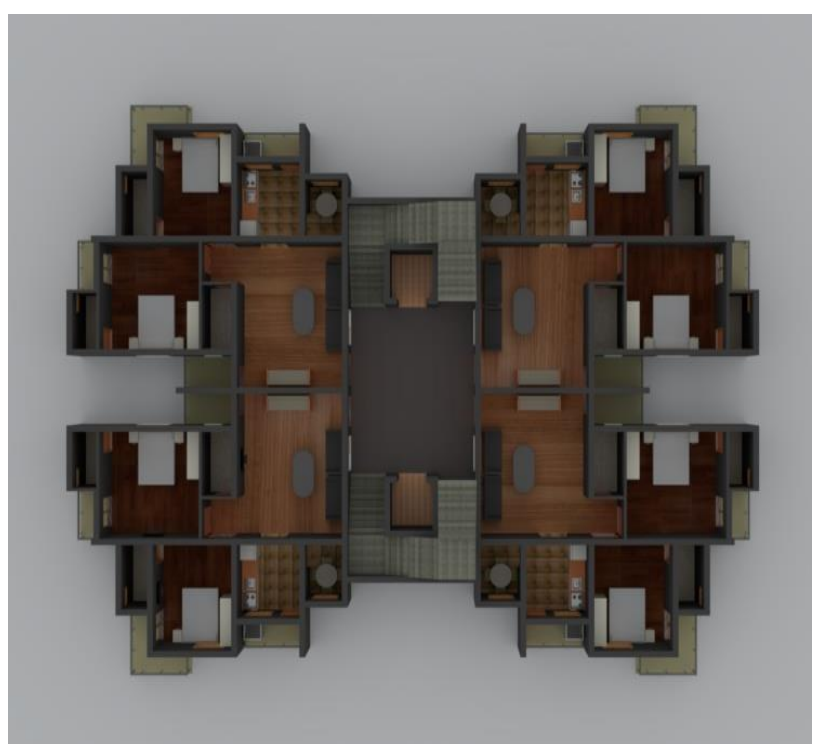

Fig 5, Architectural 3D floor plan of building.

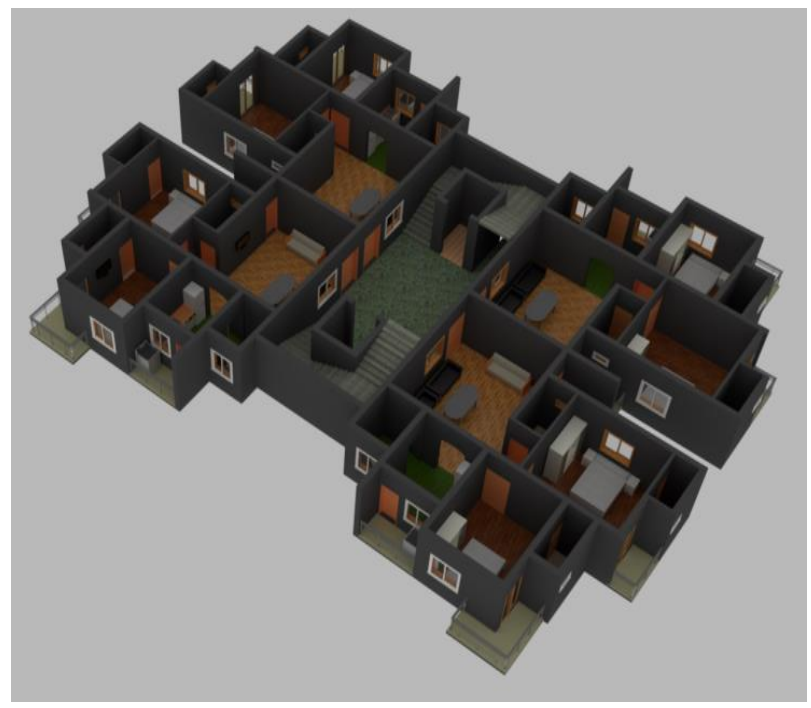

Fig 6, Architectural 3D floor plan of building.

3D elevation of building showing east side elevation rendering in Revit software Using $\mathrm{v}$ ray application, is shown in fig, 7.

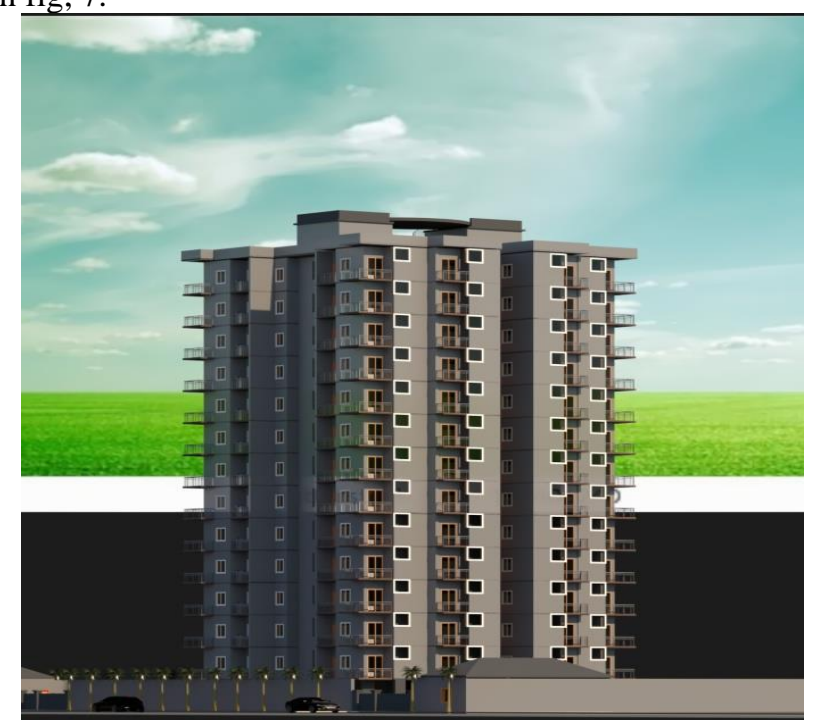

Fig 7,3D East elevation of Building.

3D elevation of building showing south side elevation rendering in Revit software using $\mathrm{v}$ ray application, is shown in fig.8.
Published By:

Blue Eyes Intelligence Engineering and Sciences Publication (BEIESP) (C) Copyright: All rights reserved.

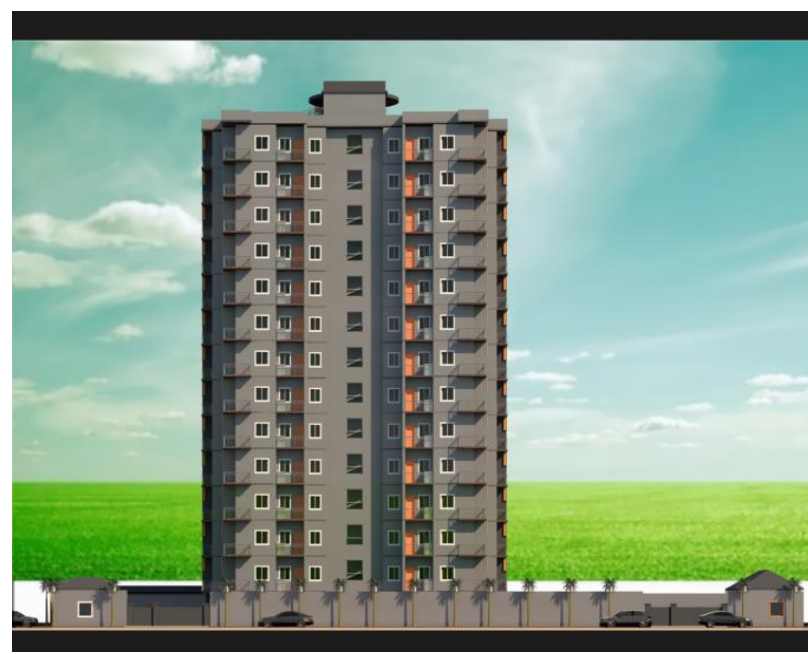

Fig 8, 3D front elevation of Building.

3D elevation of building showing west side elevation rendering in Revit software Using $\mathrm{v}$ ray application is shown in fig.9.

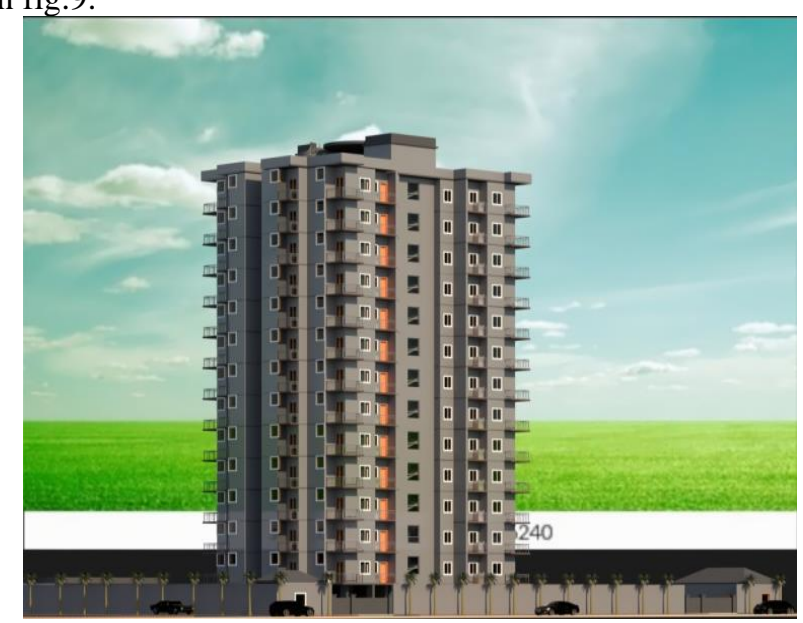

Fig 9, 3D West Elevation of Building.

3D terrace elevation of building providing helipad over the head room roof slab rendering in Revit software using $\mathrm{v}$ ray application, is shown in fig. 10 .

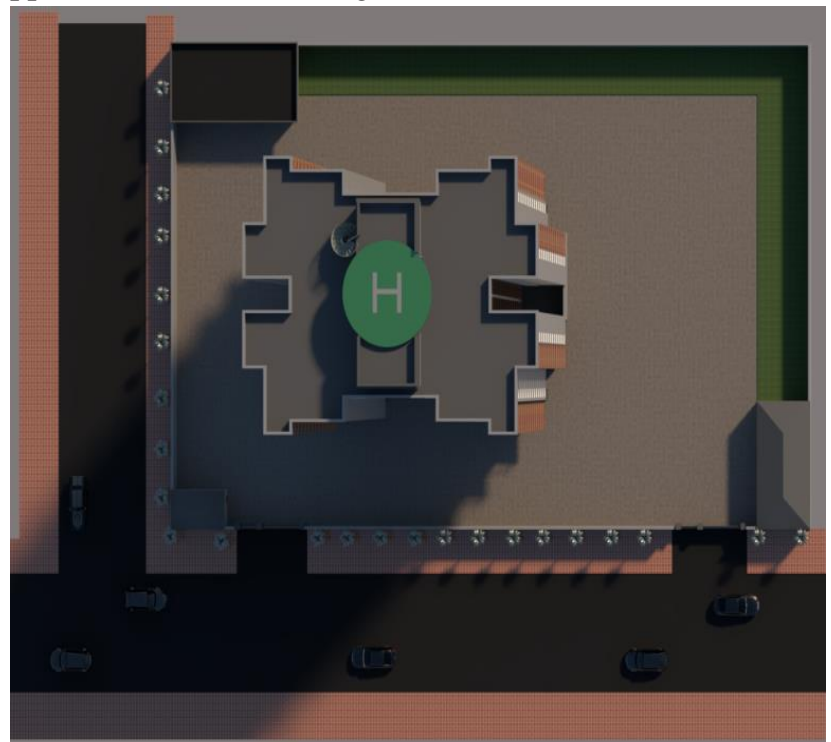

Fig 10, Architectural top view of Building in Revit

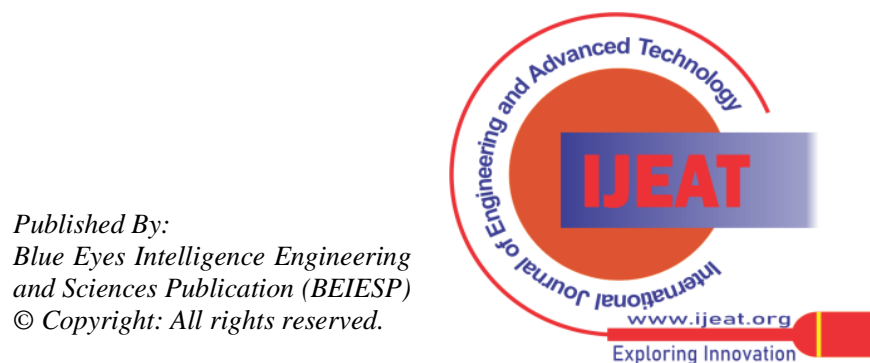




\section{ANALYSIS AND DESIGN}

\section{A. Structural Planning:}

After completing the architectural plan, the structural plan of the residential high rise building is done which involves Position and orientation of beams and columns.

\section{B. DESIGN INPUTS TO ETABS}

Sectional Properties

\section{COLUMN}

$\begin{array}{lll}\text { Grade of Concrete } & : & \text { M35 } \\ \text { Grade of Steel } & : & \text { HYSD 415 } \\ \text { Weight per Unit Volume } & : & \text { 25KN/CU.M } \\ \text { Size of Column 1 (C1) } & : & 300 \text { X 900MM } \\ \text { Column 2 (C2) } \quad \text { 300 X } & 750 \mathrm{MM} \\ \text { BEAM } & : & \text { M35 } \\ \text { Grade of Concrete } & : & \text { HYSD 415 } \\ \text { Grade of Steel } & : & \text { 25KN/CU.M } \\ \text { Weight per Unit Volume } & : & 300 \text { X 900MM } \\ \text { Size of BEAM 1 (B1) } & : 300 \text { X } & 750 M M\end{array}$

C. Load Pattern:

Codes used for design:

- IS 456-2000 code of practice for plain and reinforced concrete design.

- $\quad$ IS 875 part 1,2 and 3 for dead load, live load and wind load respectively.

- IS 1893-2016 for earthquake load.

\section{Defining loads patterns}

Reinforced concrete and prestressed concrete structures are generally designed as per Limit state method, the following load combinations are taken:

1. 1.5 (D.L +L. L)

2. $\quad 1.2(D . L+L . L \pm E X)$

3. 1.2(D. L + L. L $\pm E Y$ )

4. $\quad 1.5(\mathrm{D} . \mathrm{L} \pm \mathrm{EX})$

5. 1.5(D. $\mathrm{L} \pm \mathrm{EY})$

6. 0.9D. L $\pm 1.5 \mathrm{EX}$

7. $0.9 \mathrm{D} . \mathrm{L} \pm 1.5 \mathrm{EY}$

$$
\text { (7) Define Lod Patens }
$$

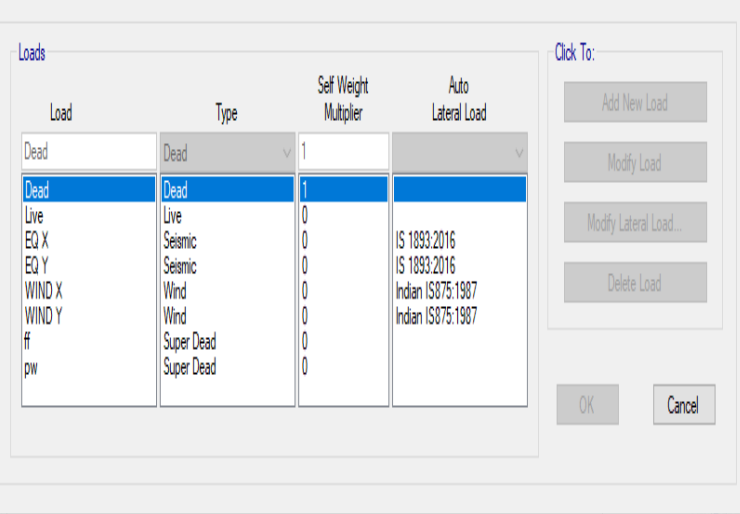

The live load for Hall, Kitchen, Bathroom and Toilet is taken as $2 \mathrm{kN} / \mathrm{m}^{2}$ For Staircase, corridors and balconies as $3 \mathrm{kN} / \mathrm{m}^{2}$ For parking area and electrical equipment room live load as $5 \mathrm{kN} / \mathrm{m}^{2}$

\section{E. MODELLING IN ETABS}

Imported floor plan centre line diagram from auto-CAD is shown in fig. 11.

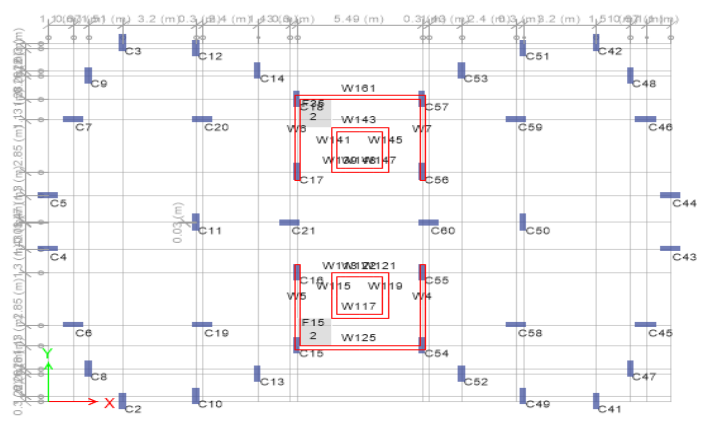

Fig11, centre line plan.

Details of 3D shell components of the building is shown in fig.12.
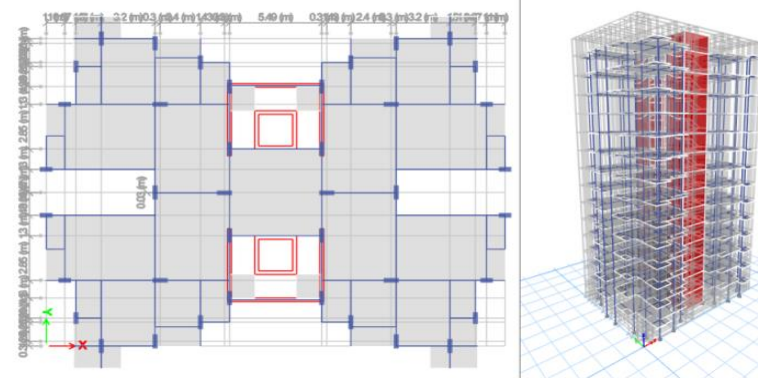

Fig 12, 3D Shell Component of High Rise Building.

2D \& 3D MODEL OF FRAME SECTION IS SHOWN IN FIG.13.
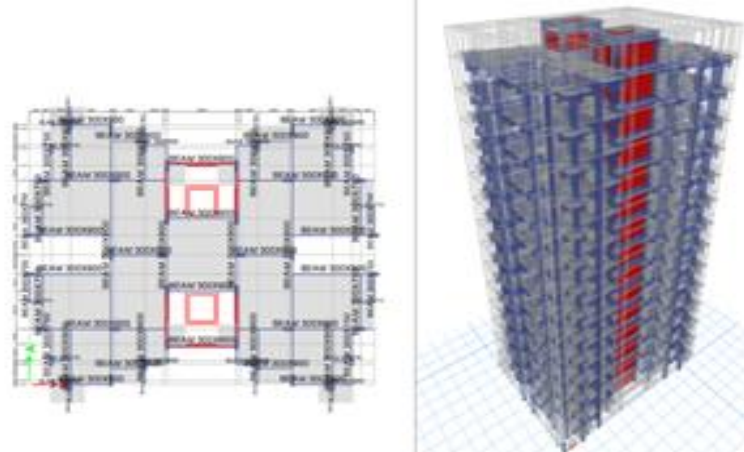

Fig13, 2D \& 3D model of frame section.

FIG.14 SHOWS THE LOAD ASSIGNED TO THE MODEL, THE ANALYZED 3D MODEL IS SHOWN IN FIG.15.

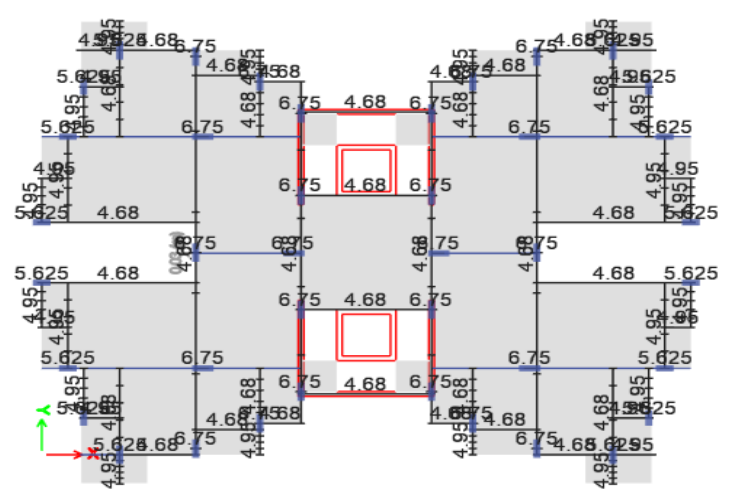

FIG 14, LOAD ASSIGNED TO THE MODEL.

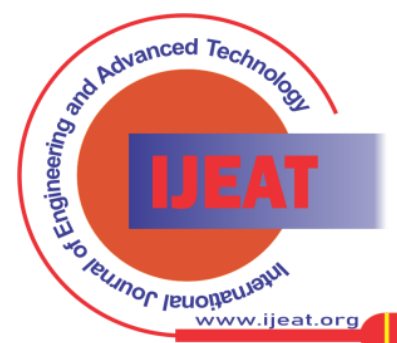




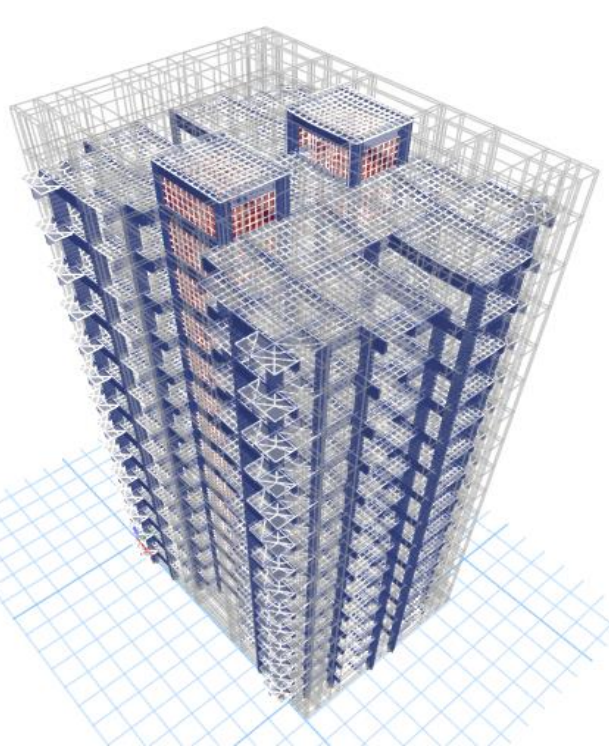

Fig 15 .Analyzed 3D model.

2D \& 3D views of Bending moment and shear force diagrams are shown in fig.16. Bending moment and shear force diagram for two typical beam elements are shown in fig.17 \& 18.
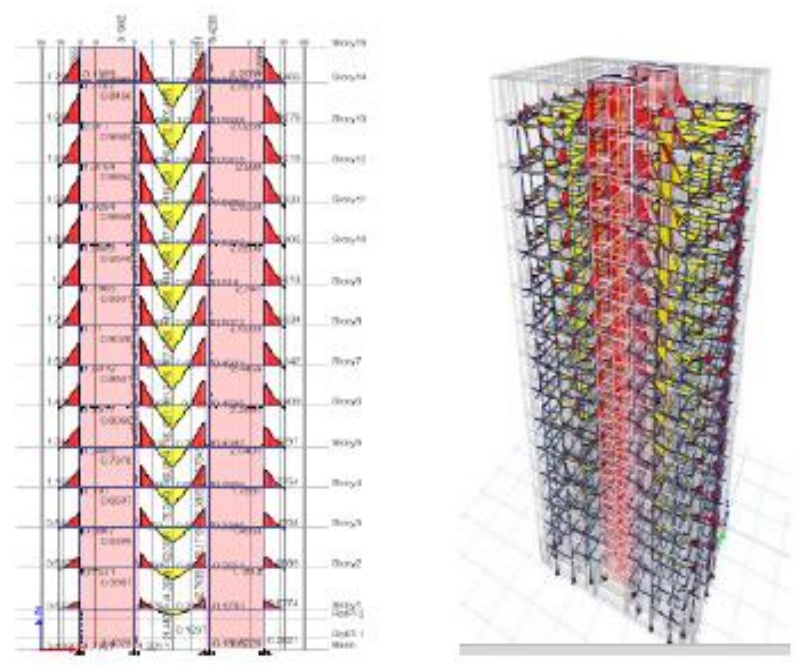

Fig 16, Bending Moment and Shear Force Diagram For The Building Frame.

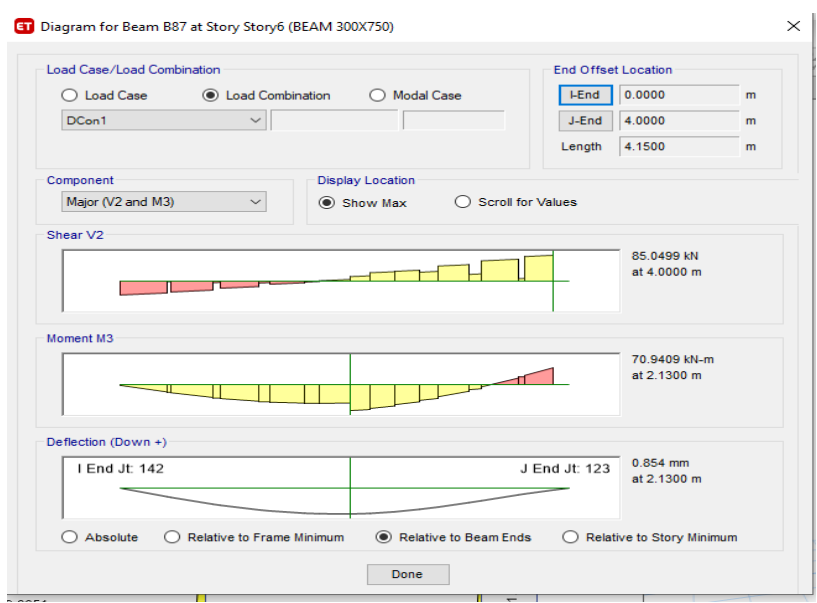

Fig 17, Shear force and bending moment values of beam (1).

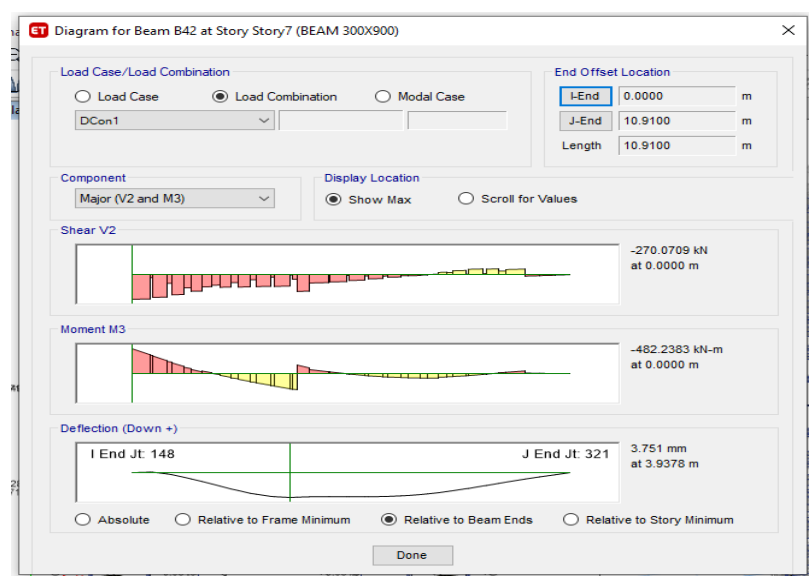

Fig 18, Shear force and bending moment values of beam (2).

$>$ The longitudinal reinforcement of columns and beams values are shown in fig.19,
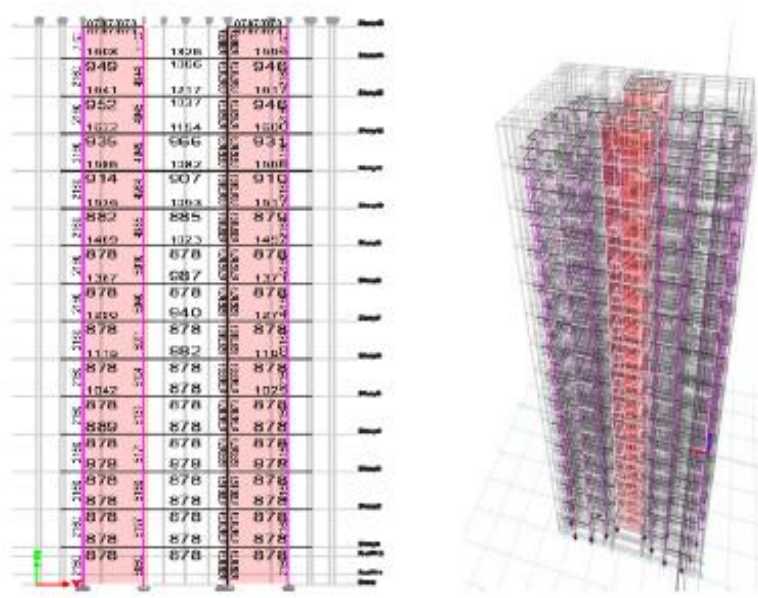

Fig 19, 3D model of structure after designed.

\section{DETAILS OF COLUMN, BEAM, SLAB, FOOTING AND STAIRCASE}

Typical design details of column and beam are shown in Table $3 \& 4$ respectively.

Table 3. Design details of Column C1 \& C2

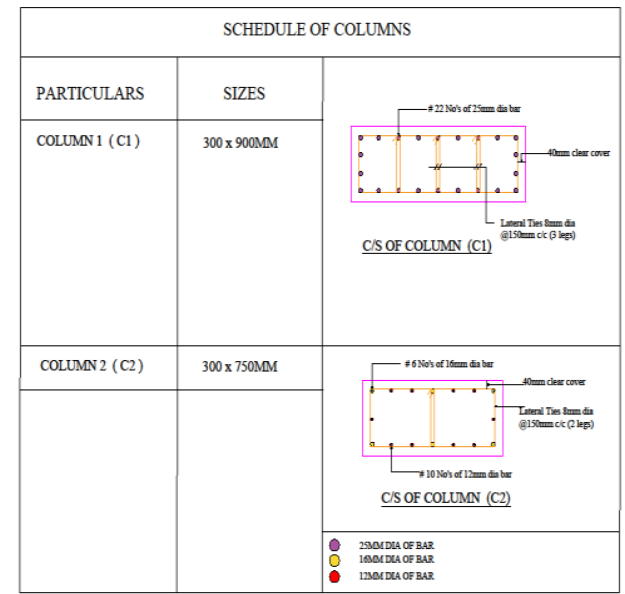

Table 4. Design details of beam B1 \& B2.

Published By:

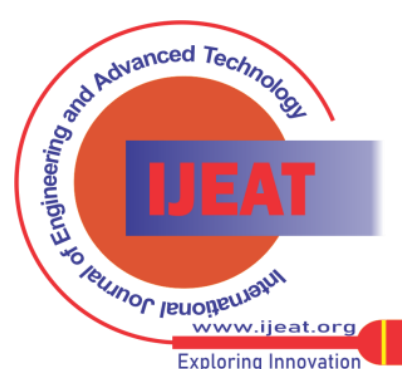




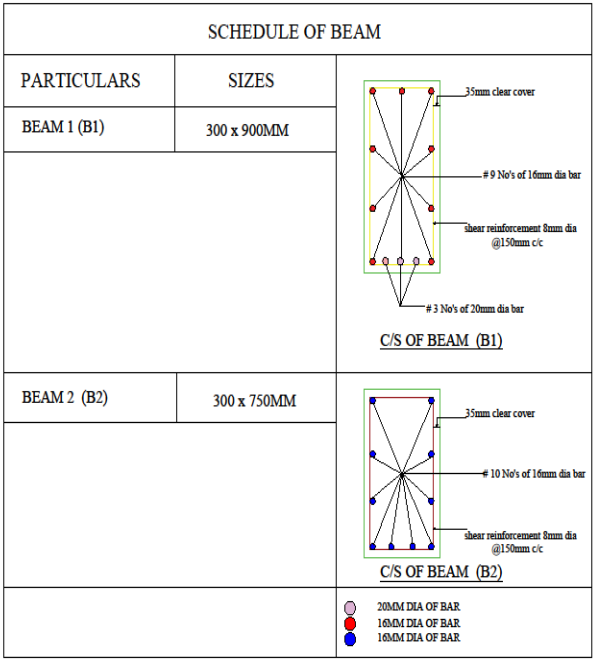

SLAB DESIGN IS CARRIED OUT USING ETABS SOFTWARE.

Fig.20, Shows Typical Slab reinforcement details:

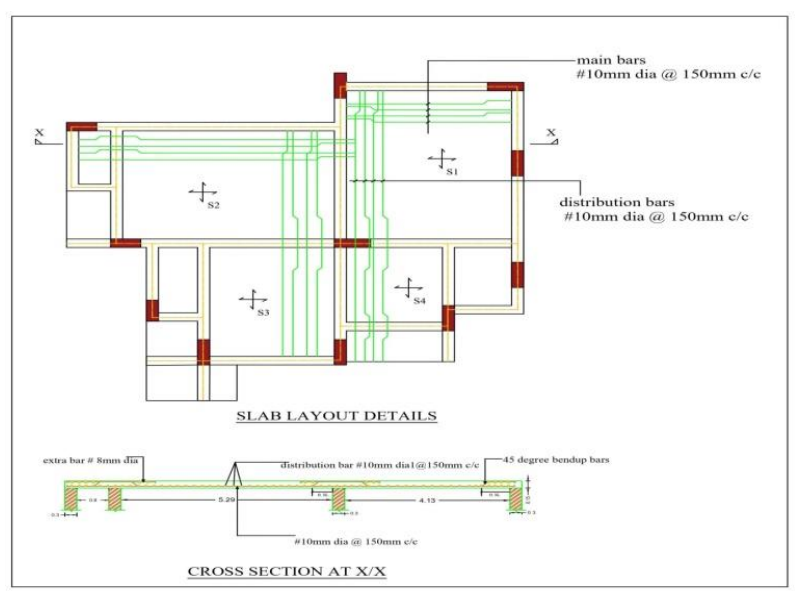

Fig.20, Slab Layout details.

FIG.21, SHOWS THE TYPICAL COLUMN AND FOOTING REINFORCEMENT DETAILS:

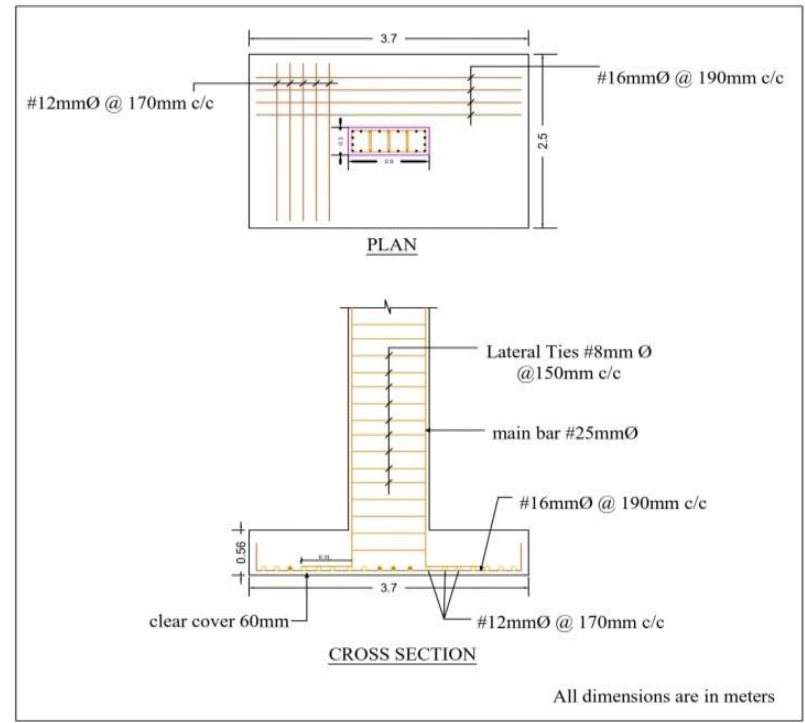

Fig.21, Column and Footing Details.

Fig.22 Shows the typical Staircase reinforcement details:

\section{Mechanical Works for the Building Project as Per}

NBC 2016.

Figure.23 shows the heating, ventilation, and air conditioning (HVAC) equipment and distribution for the present project, including air handling units (AHU), variable air volume (VAV), ducting, and air terminals.

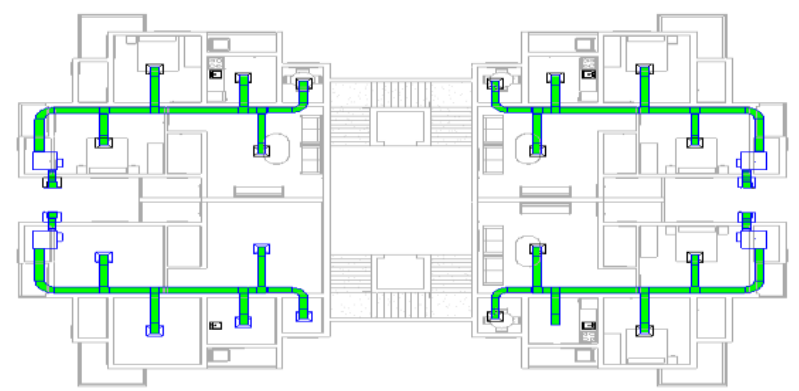

Fig.23, HVAC layout system plan.

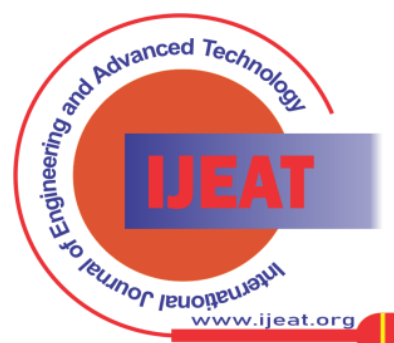


Mechanical workers handle the majority of the work in MEP because of the HVAC or air conditioning system, which includes piping for cold and hot water, duct fabrication, thermal/cold insulation, and the installation of equipment such as chillers, air handling units, diffusers, and so on. Figure. 24 shows a 3D design of the HVAC layout system for the present project's of high-rise structure.

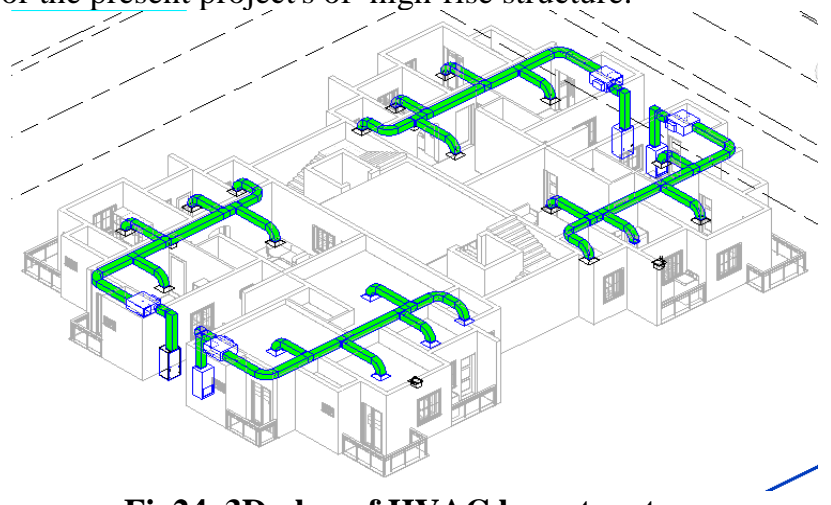

Fig24, 3D plan of HVAC layout system

Electrical Works for the Building Project as Per NBC 2016.

Coordination of Electrical System:

The electrical system include, Panel boards, switchboards, elevators, transformer, cable trays, conduits, conduits fittings etc, for the building of the project work in shown in fig. 25 .

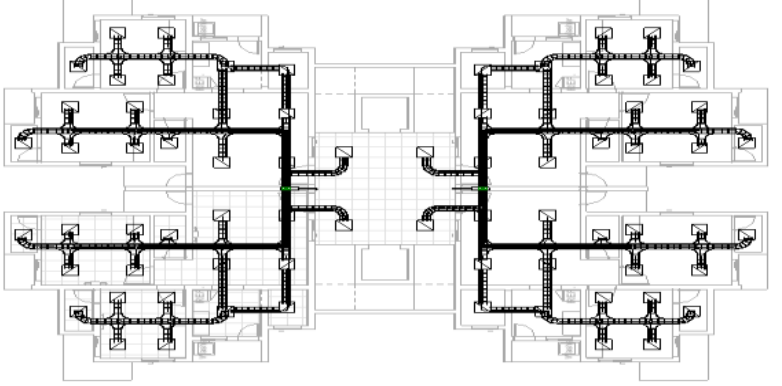

Fig25, Electrical layout system plan

$>$ The typical 3D plan layout of electrical system is shown in fig.26.

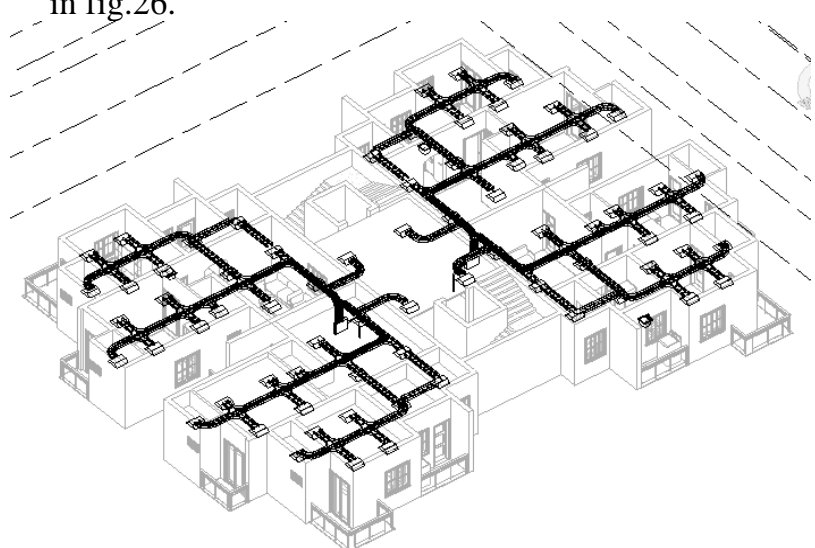

Fig26, 3D Plan of Electrical Layout System.

Plumbing Works for the Building Project as Per NBC 2016

Coordination of Plumbing System:

The system includes, water supply and sanitary arrangement. as shown below fig.27. For the building of the project work. Typical 3D plumbing layout is shown in fig.28.
Fig.29. shows a typical sectional elevation of a common toilet.

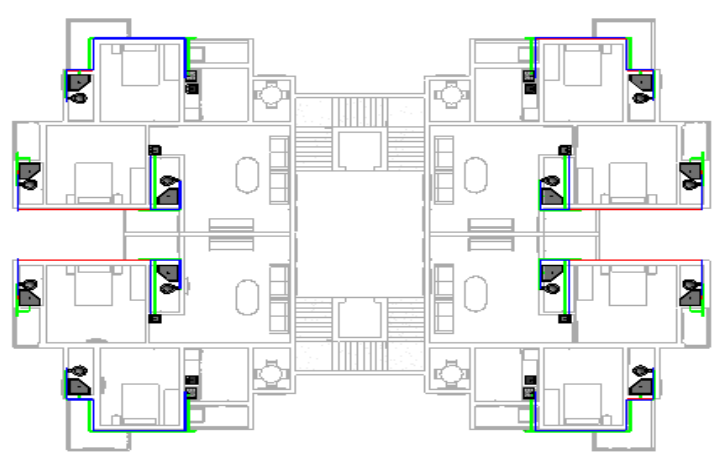

Fig27,Plumbing layout system plan

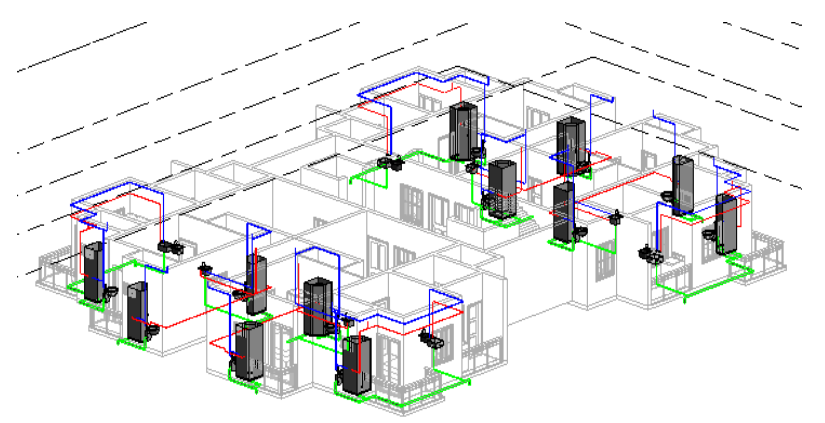

Fg28, Typical Plumbing Layout System

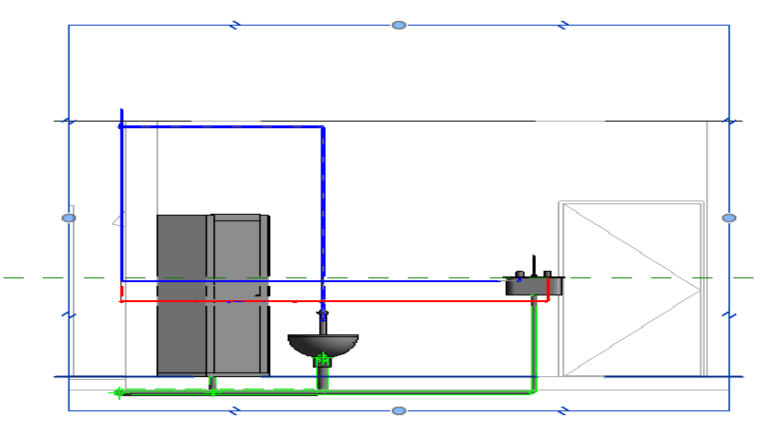

Fig29, Sectional elevation of common toilet.

Safety management system for the building as per NBC Part (4)

Fundamental studies carried out included:

i. Fire prevention.

ii. Life safety.

iii. Fire protection.

I. Fire prevention:

Classification of Buildings Based on Occupancy

a) Setback.

b) Height of building.

c) Floor area and layout.

d) Access to road.

II. Life safety:

The minimum number of exits necessary in a building should be based purely on the occupant load and the width required per person as relevant to the kind of exit for each occupancies, subject to the maximum travel distance requirement.

Published By:

Blue Eyes Intelligence Engineering and Sciences Publication (BEIESP)

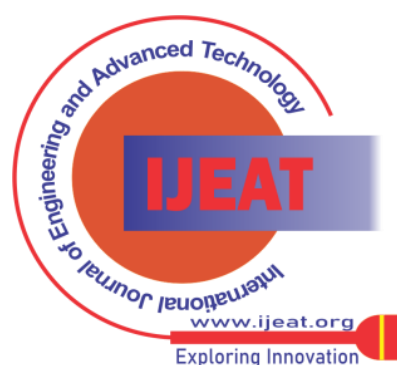


Exit access and exits are in a number of different forms.

Doors, Corridors and passageways, Staircases, Fire Detection and Alarm.

\section{Fire protection:}

Fig 30. Shows fire fighting arrangement system layout for the building schedule for the current project work.

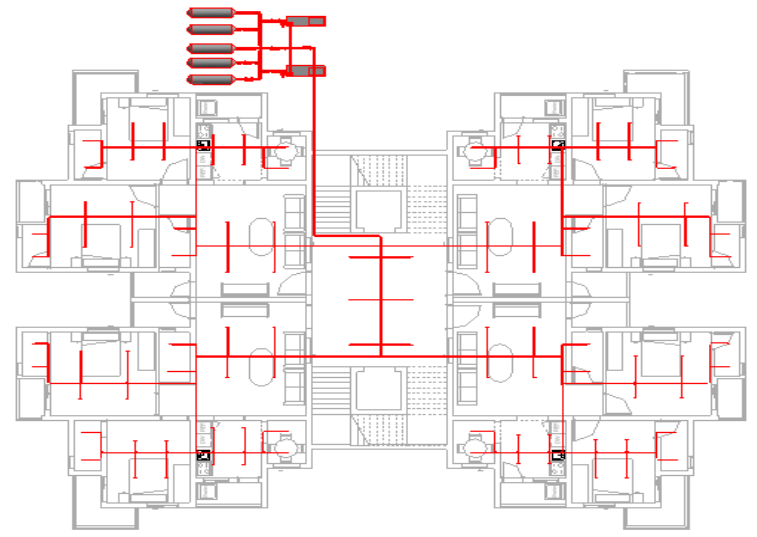

Fig30, Fire fighting arrangement system layout.

$>$ Automatic Sprinkler System

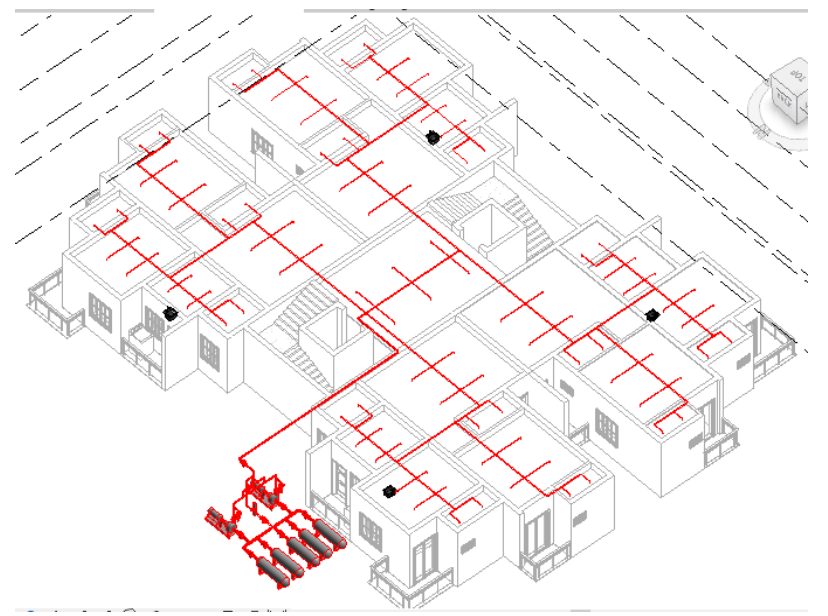

Fig.31, 3D model of fire fighting arrangement system.

\section{CONCLUSIONS:}

In the current project the modeling, design and safety management of high rise building is done by integrated use of 3 different software's in a sequential manner, which is BIM based.

Following are the conclusions:

a) The application of BIM based design process shows considerable time reduction in comparison with traditional design process.

b) The AutoCAD 2d drawings stored and transferred to a completely different software for further continuation of work in 3D.

c) 3d modeling which is done in Revit with all its specifications gives much more realistic visual of the building and overall $3 \mathrm{~d}$ building with various elevation views from different angles. By which the user can reach to any level and also to all parts of the 3D model.

d) 3d model of the building is rendered in the v.ray application to give an improved aesthetical visuals of the $3 \mathrm{~d}$ model, where in all the components can be viewed clearly.

e) The compatibility of all software's is of greater use. f) Safety management systems designed can be easily integrated with planning and designing using BIM.

\section{SCOPE FOR FURTHER WORK}

Following is the scope for further studies:

- Detailed scheduling and real time data for monitoring the construction work can be generated.

\section{REFERENCES}

1. Chandrika P, Vishnu S, Harish B N, Shriya S Nair, Varun S, Yashwanth Kumar S (2018) "Performance, Evaluation And Review Of A Multi-Storey Building Using Bim (Building Information Modelling," International Research Journal of Engineering and Technology (IRJET) Volume: 05 Issue: 07 e-ISSN: 2395-0056 p-ISSN: 2395-0072

2. Dr.R.N.UmaAndSoundarya. (2016) "Building Information Modeling In Construction Industry". International Research Journal Of Engineering And Technology (IRJET) Volume: 03 Issue: 11 | Nov -2016, P-ISSN: 2395-0072

3. E. Rakesh Reddy, S. Kailashkumar (2019) "Design And Modelling Of G+5 Commercial Building By Autodesk Revit Architecture". International Journal of Engineering and Advanced Technology (IJEAT) ISSN: 2249 - 8958, Volume-9 Issue-2, December, 2019.

4. Kim, H. And Ahn, H. (2011) "Temporary Facility Planning Of A Construction Project Using BIM (Building Information Modeling". Proceedings Of The 2011 ASCE International Workshop On Computing In Civil Engineering. Miami, FL.

5. Ku, K. And Mills, T. (2008) "Research Needs For Building Information Modeling For Construction Safety". Proceedings Of The 44th ASC National Conference, April 2-5, 2008, Auburn, Alabama USA.

6. Miss. Irin Ann Isac, Dr. Anoop C K (2019) "Analysis Of Building Information Modelling And Scope Of BIM In India". Internationa Journal Of Engineering Research \& Technology (IJERT) Vol. 8 Issue 11, November-2019 ISSN: 2278-0181

7. Mr. Shaurya Thareja Er. Jagdeesh Chand (2019) "Effective Analysis Of Highrise Structure Buildings In Autodesk Revit Bim (Building Data Modeling) Vs Autocad". International Journal of Engineering Research \& Technology (IJERT) ISSN: 2278-0181 Vol. 8 Issue 07, July-2019.

8. Sattineni A Azhar Salman,AlexBehringer And Tayyab Maqsood.(2013) "BIM For Facilitating Construction Safety Planning And Management At Jobsites" Mcwhorter School Of Building Science, Auburn University, Auburn, Alabama, USA:

9. Sayyed Feroz Sikandar1, Shaikh Zameeroddin. S2, Prof. Agrawal. A S (2019) "Analysis and Design of Multistory Building Using ETABS 2017”. ISSN 232133612019 IJESC Volume 9 Issue No. 6

10. Xiong N And Jian Tang (2017)"Research On Construction Safety Management Based On BIM", Advances In Intelligent Systems Research, Volume 156, 7th International Conference On Management, Education And Information (MEICI 2017).

11. IS. 456: 2000, Indian Standard Plain and Reinforced Concrete - Code of Practice, Bureau of Indian Standards, New Delhi.

12. IS: 875 (Part 1) - 1987, Indian Standard Code of Practice for Design Loads (Other than Earthquake) (Dead load) for Buildings and Structures, Bureau of Indian Standards, New Delhi.

13. IS: 875 (Part 2) - 1987, Indian Standard Code of Practice for Design Loads (Other than Earthquake) (Imposed Loads) for Buildings and Structures, Bureau of Indian Standards, New Delhi.

14. IS: 875 (Part 3) - 1987, Indian Standard Code of practice for design loads (other than earthquake) (Wind Loads) for buildings and structures, Bureau of Indian Standards, New Delhi.

15. IS 1893 (Part1):2016, Indian Standard Criteria for Earthquake Resistant Design of Structures, Bureau of Indian Standards, New Delhi

16. National Building Code of India 2016 Volume 1 part 4.

17. National Building Code of India 2016 Volume 2.

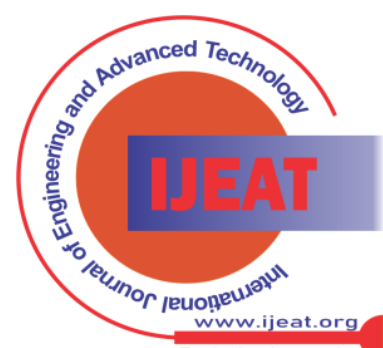


3D Modelling, Design and Safety Management in High Rise Building using Bim

\section{AUTHORS PROFILE}

Mohammed Waheed, B.E student, Department of Civil Engineering PDA College of Engineering kalaburagi-585102, Karnataka, India. Email: Mdwaheed031@gmail.com

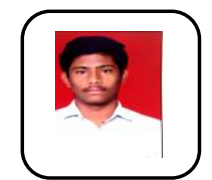

Mahmad Naheed, B.E student, Department of Civil Engineering PDA College of Engineering kalaburagi-585102, Karnataka, India. Email: nsk8616@gmail.com

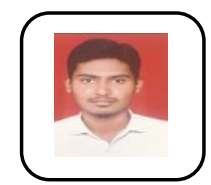

Parvez Patel, B. E student, Department of Civil Engineering PDA College of Engineering kalaburagi-585102, Karnataka, India. Email: parvezpatel2419@gmail.com

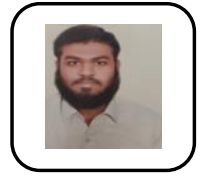

Syed Mubashir Hussain, B. E student, Department of Civil Engineering PDA College of Engineering kalaburagi-585102, Karnataka, India. Email: syedmubashir1997@gamil.com

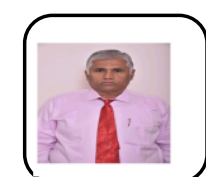

Dr Aravindkumar B Harwalkar, Associate Professor Department of Civil Engineering PDA College of Engineering kalaburagi-585102, Karnataka, India. Email: harwlkar_ab@yahoo.co.in

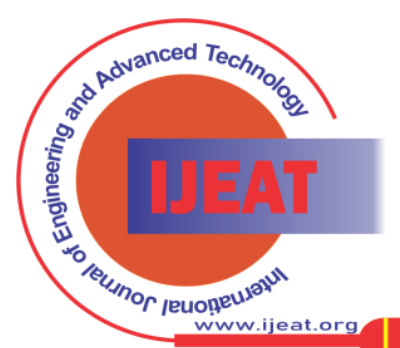

